\title{
Mafia and Organised Crime in Italy: The Unacknowledged Successes of Law Enforcement
}

\author{
LETIZIA PAOLI
}

Analysing the phenomenon of the mafia and organised crime in Italy as well as the related control policies, it is evident that, although unacknowledged by the media, policy-making and law enforcement communities, significant successes have been achieved in the fight against the mafia since the early 1990s. As a result of these successes, the Sicilian Cosa Nostra and, to a lesser extent, all other forms of southern Italian organised crime have entered a period of serious crisis. This does not mean that the Sicilian mafia is defeated or that the law enforcement repression should be relaxed.

The last 15 years have seen tremendous successes in the fight against organised crime in Italy and especially against southern Italian mafia groups. The successes of the early 1990s are publicly acknowledged: there is unanimity on the fact that the first part of that decade witnessed an unprecedented leap forward in both the fight against mafia groups and our knowledge of the mafia phenomenon. Yet the successes of the last decade are systematically understated, if not denied - a pattern that Antonio La Spina (2004) has called the 'paradox of effectiveness'. With varying degrees of good faith, most members of the law enforcement community, anti-mafia NGOs and academic and journalistic commentators insist upon the fact that from the mid-1990s onwards the anti-mafia fight dramatically slowed down and weakened. At the same time, mafia organisations, and particularly the Sicilian Cosa Nostra, are routinely portrayed as immensely powerful and almost invincible. The few observers who express less pessimistic views are harshly criticised by anti-mafia prosecutors and activists alike and accused of having lost contact with local southern Italian reality or, even worse, of serving mafia interests. ${ }^{1}$ 
There is no doubt that during the second half of the 1990s the judicial fight against the mafia lost popular and political support amid polemics about its excessive reliance on mafia defectors turned witnesses (the socalled pentiti) and investigations and trials targeting prominent politicians. However, contrary to popular perceptions, direct anti-mafia policies, which are anchored in criminal and criminal procedural law and primarily implemented by the criminal justice system, have continued to be quite effective at the beginning of the twenty-first century. Despite their programmatic hostility to the judiciary, even the governments headed by Silvio Berlusconi, who was Italy's Prime Minister for less than a year in 1994 and from June 2001 to May 2006, did not attempt any systematic reform of such policies, nor were they able to hinder substantially the anti-mafia actions of the police forces, prosecutors' offices and courts.

But our assessment is less positive regarding the wide variety of indirect anti-mafia policies primarily addressing civil society and the public administration - ranging from anti-racket legislation to the dissolution of local councils infiltrated by the mafia, and from initiatives aimed at spreading a 'legality culture' to the European Union cohesion funds that are used to promote security in southern Italy. Some of these initiatives have begun to produce results only very recently, whereas others have intrinsic deficits. The weaknesses of these indirect policies coupled with the chronic underdevelopment of the Mezzogiorno (southern Italy), are the main reasons why the fight against the mafia is far from being won. ${ }^{2}$

Nonetheless, the outcome of recent law enforcement successes is that Italian mafia organisations, and particularly Cosa Nostra, are undergoing their most serious crisis since the Fascist regime's indiscriminate mafia repression in the late 1920s. Particularly in northern and central Italy, traditional mafia groups have lost terrain to a myriad of new criminal enterprises that are much more ephemeral and often composed of foreign migrants. With the exception of some Calabrian 'Ndrangheta groups, southern Italian mafia organisations are now excluded from large-scale international flows of illegal trade and have receded into their own territories, focusing instead on racketeering in their local communities.

In the first section I present what we now know about the two largest and most powerful mafia organisations: the Sicilian Cosa Nostra and the Calabrian 'Ndrangheta. In the second section I examine how these two organisations have reacted to the intensification of the anti-mafia fight since 1992. The third section is devoted to other forms of organised crime present in Italy: I first consider the Neapolitan camorra and the myriad of Apulian gangs and then point to the growing role played by ethnic minority criminal groups as well as inconspicuous criminal entrepreneurs in Italy's illegal markets, particularly in the centre-north. The fourth section focuses on the evolution of direct and indirect anti-mafia policies since the early 1990s, before a conclusion is drawn in the final section. 


\section{Cosa Nostra and the 'Ndrangheta}

Contrary to what most scholars maintained up to the early 1980s, judicial inquiries carried out since then have demonstrated that formalised mafia groups do indeed exist. Cosa Nostra (Our Thing) and the 'Ndrangheta (Society of the Men of Honour) are the two largest and most stable criminal organisations and are each composed of about 100 mafia groups. ${ }^{3}$ Though it is not possible to establish clear lines of continuity, historical research since the late 1980s has demonstrated that antecedents of the contemporary mafia groups existed in the 1880s, if not before (e.g. Pezzino 1987). In the mid1990s the members of Cosa Nostra and the 'Ndrangheta were estimated at about 3,500 and 5,000 males, respectively (Paoli 2003: 30-2). No newer estimates have been published since then.

\section{Secret Brotherhoods}

Cosa Nostra and the 'Ndrangheta possess the distinguishing trait of organisations (Weber 1978: 48): independent government bodies that regulate the internal life of each associated family and that are clearly different from the authority structure of their members' biological families. Starting from the 1950s, moreover, super-ordinate bodies of coordination were set up - first in the Cosa Nostra, then, since the early 1990s, in the 'Ndrangheta as well. Composed of the most important family chiefs, they are known as 'commissions'. Despite the media and judicial emphasis on them, the powers of these collegial bodies have always been quite limited, as their primary and almost exclusive task has been the regulation of violence against mafia members and public officials.

Neither the Cosa Nostra nor the 'Ndrangheta can be assimilated to Max Weber's ideal type of legal-rational bureaucracy, as was suggested by Donald Cressey (1969) in the late 1960s with reference to the American La Cosa Nostra. Far from recruiting their staff and organising the latter's work according to the criteria and procedures of modern bureaucracies, mafia groups impose a veritable 'status contract' on their members (Weber 1978: 672). With the ritual initiation into a mafia group, the novice is required to assume a new identity permanently - to become a 'man of honour' - and to subordinate all his previous allegiances to the mafia membership. If necessary, he must be ready to sacrifice even his life for the mafia family.

The 'men of honour' in Sicily and Calabria are obliged to keep secret the composition, the action, and the strategies of their mafia group. In Cosa Nostra, in particular, the duty of silence is absolute. Secrecy constitutes, above all, a defence strategy. Since the unification of Italy in 1861 mafia groups have been at least formally criminalised by the state and, in order to protect themselves from arrest and criminal prosecution for their continuing recourse to violence, they have needed to resort to varying degrees of secrecy. 
The ceremony of affiliation additionally creates ritual ties of brotherhood among the members of a mafia family: the 'status contract' is also an act of fraternisation (Weber 1978: 672). The new recruits become 'brothers' to all members and share what anthropologists call a 'regime of generalised reciprocity': this presupposes altruistic behaviour without expecting any short-term reward. As F. Lestingi (1884: 453), chief prosecutor for the monarchy, pointed out, mafia groups constitute brotherhoods whose 'essential character' lies in 'mutual aid without limits and without measure, and even in crimes'.

As secret brotherhoods using violence, southern Italian mafia confederations have remarkable similarities to organisations such as the Chinese Triads and the Japanese Yakuza. With their centuries-old histories, articulated structures, and sophisticated ritual and symbolic apparatuses, all these organisations - and the American descendant of the Sicilian Cosa Nostra - have few parallels in the world of organised crime. None of the other groups that systematically traffic in illegal commodities have the same degree of complexity and longevity (Paoli 2002).

\section{The Will to Power}

Cosa Nostra and the 'Ndrangheta share another important peculiarity with the Chinese Triads and the Japanese Yakuza. Unlike other contemporary organised crime groups, they do not content themselves with producing and selling illegal goods and services. Though these activities have acquired an increasing relevance over the past 30 years, neither the trade in illegal commodities nor the maximisation of profits has ever been the primary goal of these organisations. As a matter of fact, at least in the case of southern Italian mafia coalitions, it is hardly possible to identify a single goal. The Sicilian Cosa Nostra and the Calabrian 'Ndrangheta are multi-functional organisations. In the past 100 years, their members have exploited the strength of mafia bonds to pursue various endeavours and to accomplish the most disparate tasks. Already in 1876 the Tuscan aristocrat Leopoldo Franchetti (1993: 100) pointed out the 'extraordinary elasticity' of the Sicilian associations of malfattori (evildoers): 'the goals multiply, the field of action widens, without the need to multiply the statutes; the association divides for certain goals, remains united for others'. Among these tasks the exercise of political domination has always been pre-eminent. The ruling bodies of Cosa Nostra and the 'Ndrangheta claim, above all, an absolute power over their members. They control every aspect of their members' lives, and they aim to exercise a similar power over the communities where their members reside. For a long time their power had a higher degree of effectiveness and legitimacy than that exercised by the state. In western Sicily and in southern Calabria mafia groups successfully policed the general population, settling conflicts, recovering stolen goods, and enforcing property rights. 
Even today, although most mafia rules are no longer systematically enforced, mafia families exercise a certain 'sovereignty' through a generalised system of extortion. As a state would do, they tax the main productive activities carried out within their territory (Paoli 2003: 154-72). Moreover, whenever mafiosi are asked to mediate conflicts, guarantee property rights and enforce rules compatible with their own legal order, they do not hesitate to intervene. Even contemporary 'men of honour' still take these duties seriously (e.g. Lodato 1999: 73).

The political dimension of mafia power is also proven by the fact that in the second half of the twentieth century southern Italy's mafia organisations have participated in at least three plots organised by right-wing terrorist groups. Moreover, since the late 1970s, Cosa Nostra has assassinated dozens of policemen, magistrates, and politicians. The mafia challenge to state power reached a climax in the early 1990s. In 1992, Cosa Nostra murdered the Palermitan judges Giovanni Falcone and Paolo Borsellino in two spectacular bomb explosions. In 1993, in an effort to demonstrate the national power of the mafia, a series of terrorist bombings occurred - for the first time outside traditional mafia strongholds - in Rome, Florence, and Milan.

\section{The Incomplete Entrepreneurial Transformation}

Despite their power, Cosa Nostra and the 'Ndrangheta have been unable to guarantee themselves a monopoly in any sector of the illegal economy outside southern Italy. In the early 1980s, Cosa Nostra families played a pivotal role in the transcontinental heroin trade from Asia to the United States via Sicily. But in the second half of that decade, they lost this position after being targeted by law-enforcement investigations and replaced in the US market by a plethora of Mexican, Chinese, and, more recently, Colombian heroin suppliers (Paoli 2003: 215-16). The power of Cosa Nostra is not unchallenged even within its strongholds. Given the extreme rigidity of their recruitment policies, in fact, Cosa Nostra families often find themselves in a minority position and hence are unable to control the whole underworld. This difficulty was admitted to even by Giovanni Brusca, the man who was supposed to become Totò Riina's successor in Cosa Nostra leadership, but who in fact became a mafia witness after his arrest in 1994:

Many believe that Cosa Nostra heads all criminal activities. That in Palermo or in Sicily every illegal activity is controlled by the mafiosi. People believe that prostitution and burglaries, bank robberies, and car thefts are all entries in the budget of the Mafia Inc. Those that I have just listed are external activities, known about, tolerated, and controlled by men of honour. But they are separate worlds, which only rarely come into contact with each other. In some cases, there might be 
some collaboration, but this is only in very special cases. (quoted in Lodato 1999: 67)

Despite the growing relevance of economic activities, 'the mafia has not become a set of criminal enterprises' (Becchi and Turvani 1993: 156). Its history as well as its cultural and normative apparatus prevent this transformation and today constitute a constraint as much as a resource. By building a strong collective identity, shared cultural codes and norms enhance group cohesion and create trustful relationships among mafia members. The reliance on status and fraternisation contracts, which are non-specific and long-term, produces a high degree of flexibility and makes the multi-functionality of mafia groups possible. The same shared cultural codes and norms also represent a powerful brake on entrepreneurial initiative. The prohibition on exploiting prostitution, for example, which exists in both confederations, has blocked the entrance of the Cosa Nostra and 'Ndrangheta groups into what has become one of the most profitable illicit trades: the smuggling of humans and the exploitation of migrants in the sex industry.

Especially constraining is one of the preconditions for recruitment: only men born either in Sicily or in Calabria or descending from mafia families can be admitted as members. This rule has long prevented Cosa Nostra and 'Ndrangheta families from adding new members with the experience necessary to compete in the black markets for arms, money, and gold. Rigid recruitment criteria have also hampered the geographical expansion of mafia power. Cosa Nostra, for example, prohibits settling families outside of Sicily and the only partial exception to this rule has been represented by the Cuntrera-Caruana family from Siculiana. This self-imposed rule, which aims to strengthen the cohesion of the mafia consortium, has limited its involvement in the international narcotics trade - currently the largest of the illegal markets. 'Ndrangheta families, thanks to their extensive branches in northern Italy and abroad, played a larger role in narcotics trafficking in the 1990s, importing large quantities of cocaine and hashish from Latin America and North Africa. Today, however, the 'Ndrangheta faces new competition from foreign and Italian traffickers with more direct connections to drug-producing and transit countries (Paoli 2003: 217).

The 'will to power' of the mafia organisations also negatively affects security and business decisions, as a leading Palermitan prosecutor pointed out in 1992:

The true goal is power. The obscure evil of organisation chiefs is not the thirst for money, but the thirst for power. The most important fugitives could enjoy a luxurious life abroad until the end of their days. Instead they remain in Palermo, hunted, in danger of being caught or being killed by internal dissidents, in order to prevent the loss of their 
territorial control and not run the risk of being deposed. (Scarpinato 1992: 45)

As a result, since the early 1990s Cosa Nostra and 'Ndrangheta families have extracted a growing percentage of their income from entrepreneurial activities that depend on the exercise of regional political domination. They practice systematic extortion in their communities and, thanks to intimidation and collusion with corrupt politicians, they have struggled to control the market for public works. Their interest originally focused on the construction market: from the 1950s onwards, Cosa Nostra groups, and later on 'Ndrangheta families as well, set up their own building companies and pressed claims to become directly involved in both small and large building sites. Since the 1980s, moreover, mafia enterprises of both regions have been eager to obtain a share of any public work tendered by national or local public administrations.

In addition to the spread of mafia interests, the novelty of the 1980s and early 1990s was represented by the involvement of mafia representatives in the comitati d'affari, originally formed from politicians and entrepreneurs, which had controlled the bidding processes of large-scale public works all over the country for many years. Thus mafia influence no longer took place only 'downstream', that is, at the end of the economic process of public investment (subcontracts and extortions). It was also exercised 'upstream' at the beginning of the process, with decisions made jointly by mafia representatives, state agencies and the large building companies that were particularly interested in obtaining large contracts for public works. In western Sicily, for example, a sort of 'duopoly' was established in the late 1980s and early 1990s: the public works market was subject to the complete 'top-down' control of two strong groups - Cosa Nostra and the comitati d'affari - which had joined forces in a kind of symbiosis cemented by silence and complicity (Paoli 2003: 147-8, 174-5).

Unlike other Western forms of organised crime, the meaning (and danger) of the two main Sicilian and Calabrian mafia organisations cannot be limited to their involvement in illegal markets. Their peculiarity lies in their will to exercise political power and their interest in exercising sovereign control over the people in their communities.

\section{Law Enforcement Repression and Mafia Organisations' Reactions}

Cosa Nostra and the 'Ndrangheta's economic activities, political relationships and even their overall associational life have been seriously hit by the intensification of law enforcement action that followed the 'terrorist' attacks staged by Cosa Nostra in 1992-93. The attacks against Cosa Nostra were particularly devastating, as allegedly recognised even by Bernardo Provenzano, the latest known capo, or chief of the Sicilian mafia organisation, who was captured in April 2006. According to an informant, 
in fact, in the second half of the 1990s, Provenzano said that he was convinced that Cosa Nostra would need at least five to seven years to recover from the serious crisis into which it had plunged and to improve its economic situation, which was at that point precarious (Ministero dell'Interno 2001a: 10).

\section{The State Counterattacks after 2002}

Provenzano's arrest in 2006 crowned the intensified law enforcement efforts to capture all the leading Cosa Nostra figures of the 1980s and 1990s, some of whom had been on the run for decades. The first outcome of such an effort and a major boost for the whole anti-mafia campaign had been the arrest in January 2003 of Totò Riina, Provenzano's predecessor at the head of Cosa Nostra, after more than 22 years spent in hiding. Between these two spectacular arrests, hundreds of less well-known mafia members were also arrested and tried. The Direzione Investigativa Antimafia (DIA 2007) reports that in the period 1992-June 2006 it allowed prosecutor's offices to issue 1,627 arrest warrants against members of Sicilian mafia groups and 2,317 against members of the Calabrian mafia. These data do not of course represent the total number of arrested persons. Another partial source is the Ministry of the Interior, which reports the data concerning the dangerous fugitives, most of whom are mafia bosses or at least mafia members. As Table 1 shows, between 1992 and 2005 over 1,200 fugitives were arrested, who belonged to either Sicilian or Calabrian mafia groups.

TABLE 1

ARRESTED FUGITIVES BELONGING TO EITHER CALABRIAN, SICILIAN, OR CAMPANIAN ORGANISED CRIME GROUPS, 1992-2005

\begin{tabular}{lccc}
\hline & $\begin{array}{c}\text { Calabrian mafia } \\
\text { groups }\end{array}$ & $\begin{array}{c}\text { Sicilian mafia } \\
\text { groups }\end{array}$ & $\begin{array}{c}\text { Campanian camorra } \\
\text { groups }\end{array}$ \\
\hline 1992 & 29 & 12 & 24 \\
1993 & 47 & 69 & 30 \\
1994 & 34 & 71 & 44 \\
1995 & 59 & 90 & 43 \\
1996 & 66 & 56 & 49 \\
1997 & 34 & 39 & 33 \\
1998 & 86 & 80 & 122 \\
1999 & 53 & 50 & 111 \\
2000 & 43 & 38 & 111 \\
2001 & 44 & 25 & 59 \\
2002 & 38 & 25 & 58 \\
2003 & 22 & 26 & 33 \\
2004 & 30 & 18 & 48 \\
2005 (six months) & 16 & 5 & 25 \\
Total & 601 & 604 & 790 \\
\hline
\end{tabular}

Source: For 1992-97, Ministry of the Interior 2001b: 438; for 1997-2005, Ministry of the Interior 2005a: 26-7. 
Neither the DIA nor the Ministry of the Interior distinguish between members of Cosa Nostra and 'Ndrangheta families and members of other mafia or pseudo-mafia crime groups active in Sicily. However, there is no doubt that the former account for the bulk of mafia-type organised crime in the two regions and they are prioritised by law enforcement agencies. Given the previous estimates of 3,500 and 5,000 males respectively composing Cosa Nostra and the 'Ndrangheta, it is clear that the probability of being arrested has become very high.

Members of Cosa Nostra and 'Ndrangheta are not only arrested but also charged and convicted, with heavy sentences being imposed. Even in Calabria, where state repression has until recently not received much support from civil society, mafia groups have experienced severe restrictions. In January 1999, at the end of the hearings concerning the Olimpia-1 Operation, the Reggio Calabria court handed down 62 life sentences and 141 sentences amounting to over 1,380 years of imprisonment, while another 300 defendants are involved in the three following parts of the inquiry (Gazzetta del Sud, 20 January 1999). Likewise, the 99 defendants of the Tirreno maxi-trial, which took place in Palmi against the greatly feared Piromalli and Molè families, were sentenced to 89 life sentences and 731 years of imprisonment by the local first-degree court. The investigations did not focus only on the core families of the province of Reggio Calabria, but also involved their branches in central and northern Italy. In Milan, for example, between 1994 and 1998 more than 1,000 members of the 'Ndrangheta faced trial in about 20 maxi-trials, all of which ended with convictions and heavy sentences (Paoli 2003: 214).

Although they do not provide regional specification, the data of the Department of Penitentiary Administration confirm that the risk of spending a long time in jail has become real for mafiosi. In December 2005 , for example, a total of 5,684 persons were serving sentences for the crime of mafia association foreseen by Article 416bis of the Italian Criminal Code, including 5,514 male Italians, 45 female Italians, 177 male foreigners and 8 female foreigners (Ministero della Giustizia 2006). Of those, 672 mafiosi were held under the special incarceration regime (Art. 41bis of the penitentiary law) as of the end of December 2002. The imprisoned chiefs were so discouraged that in early 2001 some of them allegedly proposed a deal to the state institutions: they would confess to their own crimes, without involving other mafia members, in exchange for a reduction in their convictions and the abolition of the special detention system (La Repubblica, 6 February 2001: 15).

The financial drain on the two organisations has been especially heavy. During the Olimpia-1 trial, for example, the Reggio Calabria court seized properties worth almost $€ 80$ million and confiscated goods worth over $€ 20$ billion definitively (Gazzetta del Sud, 20 January 1999). According to the prefect of Reggio Calabria, assets worth $€ 700$ million were seized in the province during the 1990s (CPM 2000: 51). The DIA (2007) alone claims 
to have seized assets worth over $€ 1$ billion from Sicilian mafia groups. Whereas the precision of these estimates may be questioned, ${ }^{4}$ qualitative evidence confirms the overall impact. Indeed, some mafia families now seem to be virtually bankrupt as a result of seizures and sentences. According to several law enforcement investigators, during the second half of the 1990s many mafia groups, both in Palermo and in Reggio Calabria, stopped paying the monthly salary to the families of the convicted 'men of honour', thus ending one of the most important principles of the mafia legal order because they no longer had liquidity (DIA 2007: 58).

The new investigations were frequently promoted by confessions from former mafia members, dozens of whom decided to become state witnesses after the early 1990s. At its peak, in late 1996, more than 1,200 former members of criminal groups were under the state protection programme. About 35 per cent of these formed part of Sicilian crime coalitions. The percentage of pentiti coming from the ranks of Calabrian mafia and pseudomafia groups, which rely more than Cosa Nostra on family blood ties, was more modest (13 per cent) (Ministero dell'Interno 1997). The sudden rise in the number of mafia witnesses was made possible by the adoption of legislation granting them sanctioning and penitentiary benefits and establishing a state protection programme in 1991 (see below). However, the sudden rise in their number also reflects the crisis of the mafia legitimation system following the modernisation of southern Italy and the partial 'entrepreneurial transformation' of mafia groups, which was aggravated by Cosa Nostra's more and more indiscriminate use of violence in the late 1980s and early 1990s (Paoli 2003: 94-8).

Mafia witness confessions and statements allowed not only investigations and arrests but also inquiries into what is sometimes inappropriately called the 'third level': namely the political and judicial protection mafia groups enjoyed for decades. The three most sensational investigations and trials begun in the early 1990s - namely, the two involving Giulio Andreotti, ${ }^{5}$ accused in Palermo of belonging to a mafia-type delinquent association and in Perugia of having ordered the murder of journalist Mino Pecorelli in 1979, and the trial against Corrado Carnevale, the former head of the first section of the Corte di Cassazione - largely backfired, as the two defendants were finally acquitted of all charges. Andreotti's acquittal, however, was not stainless. The Palermitan judges in fact pointed out that Andreotti, together with some Sicilian Christian Democrats, had close relationships with Cosa Nostra before 1980, though they applied the statute of limitations for that period. Moreover, with less media outcry, several other politicians have been brought to trial accused of favouring mafia groups and some of them have been convicted - among them, Marcello Dell'Utri, Silvio Berlusconi's former right-hand man, who was convicted by a first-degree Palermitan court for his support for Cosa Nostra. 


\section{Cosa Nostra and the 'Ndrangheta's Reactions and Current Conditions}

Cosa Nostra and the 'Ndrangheta have responded in several ways to escape law enforcement action or at least to minimise its impact. For Cosa Nostra this has meant a reversal of the open challenge to state sovereignty pursued in the early 1990s. The radical change of strategy has not been accompanied, however, by a significant change of leadership: Bernardo Provenzano who used to be Cosa Nostra's undisputed leader until his arrest in 2006, was Totò Riina's right-hand man in the 1980s and early 1990s.

The first goal of both organisations' reforming efforts has been to become as invisible and impermeable to law enforcement agencies as possible. In line with this objective, except for the anomalous murder of the vice-president of the Calabrian regional assembly, Francesco Fortugno in October 2004, no murders of civil servants or terrorist attacks have been authorised. Within Cosa Nostra, rigid procedures have also been established to authorise the murder by 'men of honour' of other mafia members or petty criminals. This new policy has had tangible results, as Table 2 reveals. Since the early 1990s there has been a dramatic decrease in the number of murders, and specifically organised crime-related murders, recorded in Sicily and Calabria. In 2003 mafia murders committed in Sicily were a twenty-fifth of those recorded in the peak year of 1991, while in Calabria they fell to a sixth.

Allegedly, Provenzano has also asked his mafia brothers to focus on entrepreneurial activities that do not raise too much social alarm, such as

TABLE 2

MURDERS AND ORGANISED CRIME-RELATED MURDERS REPORTED IN CALABRIA, SICILY AND CAMPANIA

\begin{tabular}{|c|c|c|c|c|c|c|}
\hline & \multicolumn{2}{|c|}{ Calabria } & \multicolumn{2}{|c|}{ Sicily } & \multicolumn{2}{|c|}{ Campania } \\
\hline & Murders & $\begin{array}{l}\text { Org. crime } \\
\text { murders }\end{array}$ & Murders & $\begin{array}{l}\text { Org. crime } \\
\text { murders }\end{array}$ & Murders & $\begin{array}{l}\text { Org. crime } \\
\text { murders }\end{array}$ \\
\hline 1990 & 326 & 141 & 428 & 150 & - & 201 \\
\hline 1991 & 277 & 165 & 481 & 253 & 378 & 232 \\
\hline 1992 & 151 & 46 & 399 & 200 & 290 & 181 \\
\hline 1993 & 126 & 43 & 252 & 85 & 197 & 86 \\
\hline 1994 & 121 & 42 & 249 & 90 & 165 & 65 \\
\hline 1995 & 95 & 24 & 223 & 88 & 228 & 113 \\
\hline 1996 & 103 & 30 & 180 & 66 & 204 & 94 \\
\hline 1997 & 100 & 32 & 131 & 34 & 185 & 103 \\
\hline 1998 & 85 & 28 & 140 & 35 & 199 & 107 \\
\hline 1999 & 82 & 26 & 116 & 28 & 151 & 65 \\
\hline 2000 & 84 & 34 & 86 & 13 & 163 & 73 \\
\hline 2001 & 88 & 28 & 82 & 20 & 127 & 57 \\
\hline 2002 & 61 & 17 & 70 & 11 & 109 & 47 \\
\hline 2003 & 69 & 26 & 61 & 10 & 125 & 70 \\
\hline
\end{tabular}

Source: ISTAT, Annuario Statistische Giudiziarie Penali, several years. 
extortion, usury, manipulation of public tenders and, to the extent possible, drug trafficking. Changes are also recorded in the very organisation of extortions. According to the DIA, all producers, and not just the big companies as in the past, are now asked to pay a contribution to Cosa Nostra, but contributions are kept low to prevent popular resentment from reaching critical levels (Ministero dell'Interno 2006a: 20-1).

To ensure cohesion and reduce the number of potential defectors, Provenzano, according to the DIA, also envisaged and implemented a fullyfledged plan with three main pillars:

- returning to Cosa Nostra's traditional rules, which had in the past allowed the organisation to operate inconspicuously;

- drastically reducing the number of 'men of honour', forming in fact a criminal elite set apart from 'manpower', to create some layers of protection around 'men of honour' and thus protect them from possible defectors among low-ranking staff;

- raising the cultural standard of Cosa Nostra leaders and members, by recruiting candidates with high educational standards and a good social position (Ministero dell'Interno 2000).

To protect himself from possible defections, Provenzano also relied on a small number of trusted mafiosi, who were given responsibilities over and above the traditional organisations in families and districts (the so-called mandamenti) (Ministero dell'Interno 2001a). According to several sources, even the Palermitan provincial commission (undoubtedly Cosa Nostra's most consolidated collegial body) has not held full meetings since 1994. Up until his arrest, Provenzano used to communicate primarily with his trusted lieutenants via so-called pizzini - short, hand-written or typed letters that were delivered back and forth by chains of trusted postmen. Ironically, this communication system, which had been dictated by security reasons, has now turned into an unexpected and very rich source of information and evidence against high-ranking Cosa Nostra members.

The pizzini themselves, as well as the numerous wiretappings of conversations among mafiosi, also attest to the economic and political decline of Cosa Nostra. While international drug trafficking continues to be an important activity for some 'Ndrangheta families, particularly those of the Ionian coast, Cosa Nostra groups are by now largely marginalised. 'To illustrate how Cosa Nostra's role in drug trafficking has changed', the DIA wrote in one of its bi-annual reports, 'it is enough to point out that the Bagheria family, which once had a prominent role in heroin trafficking towards the United States, has now turned to supplying a dealers' network in Palermo' (Ministero dell'Interno 2000: 11). Extortion currently represents the primary and most stable source of revenue for most Cosa Nostra families. Thus, far from profiting from Cosa Nostra and the 'Ndrangheta's entrepreneurial difficulties, people and companies in 
high-density mafia districts are today exploited by the mafiosi more than ever, as they are called to make up for the failed earnings from drugs or other illegal trades.

All of the units of the two mafia confederations place their hopes for economic recovery in gaining public contracts, which began to be distributed from 2000, after the sharp drop, especially in the South, following the Tangentopoli ('Bribesville') inquiries (see Della Porta and Vannucci 2007). Cosa Nostra and 'Ndrangheta families have been particularly eager to intercept part of the considerable sums from the EU funds of Agenda 2000: approximately $€ 9,000$ and $€ 5,000$ million, respectively, were invested between 2000 and 2006 in Sicily and Calabria. However, the extent to which the mafia groups have been able to achieve their objectives is unclear. A coordination committee for the supervision of major public works, composed of representatives of law enforcement agencies and several national ministries, began to operate in 2003 and has so far failed to find evidence of large-scale mafia infiltration in major infrastructural investments. Indeed, even Provenzano's pizzini seem to prove Cosa Nostra's current inability to influence the allocation of large-scale projects in contrast to predominant and more successful involvement in more local and limited tenders (Loi 2006).

Cosa Nostra and 'Ndrangheta families still enjoy a local network of trusted politicians, most of whom are members of the Unione dei Democratici Cristiani (UDC) or Forza Italia: it suffices to mention that Salvatore Cuffaro (UDC), the President of Sicily, is currently under trial for abetting Cosa Nostra. During the five years of Berlusconi's second and third cabinets, mafia bosses had also hoped that the many southern Italian lawyers who routinely represented mafiosi and had been elected to Parliament in the ranks of the government coalition would reform current anti-mafia policies. As we will see below, however, their hopes were largely frustrated, despite the not-so-veiled threats from imprisoned bosses. As Francesco Messina Denaro summed up in a pizzino to Provenzano, 'we have been hit hard ... if they [the law enforcement agencies] go on so, they will not only arrest all of us but even our chairs'. Messina Denaro went on asking Provenzano for political help, but he then added himself: 'they [the politicians] do not do anything for nothing. And at the moment, we do not have much leverage over them' (Cordella 2006: 7).

\section{Other Forms of Organised Crime in Italy}

In addition to the Sicilian Cosa Nostra and the Calabrian 'Ndrangheta, two other clusters of crime groups are usually referred to as organised crime in Italy: 1) the 'galaxy' of mafia-like and gangster-like groupings in Campania, collectively known as 'camorra'; and 2) the multiplicity of criminal groups, gangs and white-collar criminal networks operating in Apulia. 


\section{The Camorra}

The camorra consists of a variety of independent criminal groups and gangs. A few of them are well-established family businesses that, similarly to their Sicilian and Calabrian counterparts, claim to exercise a political dominion over their neighbourhoods and villages and systematically infiltrate local government institutions. At certain points they have enjoyed the protection of high-level national politicians as well. Other camorra groups are more ephemeral formations that have developed around a charismatic chief, usually a successful gangster. Finally, there are also loose gangs of juvenile and adult offenders, which - according to police sources - belong to the sphere of common crime rather than organised crime (Ministero dell'Interno 2001c: 60-5).

To strengthen their legitimacy and cohesion, many of these groups frequently resort to the symbols and rituals of the nineteenth-century camorra. This was an organisation sharing several cultural and organisational similarities with its Sicilian and Calabrian counterparts, though it distinguished itself by its concentration in the city of Naples, the capital of the region of Campania, and its plebeian background. Unlike Cosa Nostra and the 'Ndrangheta, however, the contemporary Campanian underworld does not directly derive from its nineteenth-century forerunner. As Isaia Sales (2001: 468) puts it, 'if camorra means a criminal organisation that ruled over Naples' popular and plebeian strata, we can safely say that it started and ended in the nineteenth-century'.

The camorra was 'born again' in the 1960s thanks to the expansion of smuggling in tobacco and later in drugs. In the 1980s, several camorra groups and brief coalitions of groups (above all, the Nuova Camorra Organizzata and the Nuova Famiglia) subsequently gained great wealth and power by appropriating the flows of public money invested in Campania after the earthquake of 1980 (Monzini 1999). Despite their extensive infiltration of the legitimate economy and the public administration, however, contemporary camorra groups have not succeeded in establishing stable coordination mechanisms such as those of the nineteenth-century camorra or of the Sicilian and Calabrian mafia organisations. As a result, Campania has had the highest rate of murders and violent crime in all of Italy for more than a decade.

Especially in the last few years, a number of shoot-outs and murders in central city neighbourhoods in full daylight have raised social and political alarm. Paradoxically, some of these conflicts are unwanted side effects of the law enforcement successes. The weakening of the most powerful criminal clans has left open spaces for a variety of middle-sized and small crime groups that often fight each other for control of the local territory. Several conflicts have also erupted within large criminal groups when lieutenants have challenged the power of the group leaders to gain control of the most profitable activities, often exploiting the leaders' judicial 
difficulties. In 2004, for example, the so-called 'secessionists' revolted against the leadership of the clan Lauro, one of the largest in the Naples metropolitan area, and the subsequent struggle led to dozens of murders. In rarer cases, violent conflicts pitch two or more structured and powerful groups against each other. In the late 1990s, for example, a violent and devastating fight involved two coalitions of Neapolitan clans (the Alleanza di Secondigliano and coalition Misso, Mazzarella, Sarno) before they split up areas and activities of interests around the year 2000 (Ministero dell'Interno 2005a: 43-4; 2006a: 21-2). In November 2006, the Ministry of the Interior reacted to one of the latest sensational killings with the enactment of a Security Pact for Naples, strengthening the local police forces and committing them to a more complete control of the territory.

Despite these repeated conflicts, the official statistics (reported in the last two columns of Table 2) show that even in Campania murders and organised crime-related murders declined considerably during the 1990s and into the twenty-first century. With twice as many murders as those recorded in 2003 in Sicily or Calabria, Campania has, however, experienced a less pronounced decline. In the current period, moreover, roughly half of all organised crime-related murders committed in the country have taken place in Campania (Ministero dell'Interno 2005b: 14a). This more gradual decline should not be interpreted as a sign of weaker repression by law enforcement agencies. In Campania, too, criminal gangs have been hit very hard since the early 1990s. To give just one example, 790 fugitives were arrested in Campania between 1992 and June 2005, almost 200 more than either in Calabria or Sicily (see Table 1).

The heterogeneity and anarchy of the Campanian underworld is also revealed by the great variety of entrepreneurial activities in which the local crime groups are involved. The most powerful camorra clans are still able to influence and control the local legitimate economy, despite the far-reaching investigations conducted by law enforcement agencies in the 1990s. The smaller groups and gangs engage in all sorts of illegal activities - extortion, fraud, drug trafficking and dealing, loan-sharking, counterfeiting and the exploitation of prostitution - and are ready to resort to violence whenever they see their 'turf' and activities being threatened (Ministero dell'Interno 2001c: 60-75; see also Saviano 2006).

\section{The So-called Apulian Organised Crime}

The development of Apulian 'organised crime' goes back to the 1970s when the region became Italy's major import point for smuggled cigarettes and was 'colonised' by neighbouring mafia and camorra groups. In the following years, indigenous crime groups and gangs sprang up in different parts of Apulia. The most successful of these was for a long time the Sacra Corona Unita, a consortium of about 10 to 15 criminal groups and gangs from 
southern Apulia, which was founded in 1983 (Massari 1998). Contrary to media accounts, the Sacra Corona Unita has never controlled the whole of Apulian organised crime; despite its imitation of the 'Ndrangheta's structure and rituals, its cohesion and stability have always been much lower. Today, after the defection of some of its leaders and the arrest of most of its members since 2000, the Sacra Corona Unita no longer exists as a single viable organisation (Ministero dell'Interno 2002: 57-64).

Notwithstanding the decline of the Sacra Corona Unita, illegal business activities continue. Up until the early 1990s, tobacco smuggling was the main source of revenue for most Apulian criminal enterprises. Since then, however, the latter have diversified their investments, exploiting their strategic geographical position to smuggle drugs and migrants from nearby Balkan countries. In the last few years, as the improved cooperation of Italian and Albanian police forces has resulted in an intensified repression of tobacco smuggling, Apulian crime groups have also started to engage in extortion, usury, robberies and counterfeiting to compensate for their losses of revenue.

\section{The New 'Foreign Mafie' and Inconspicuous Players}

The expressions 'organised crime' and 'mafie' are also increasingly used to refer to foreign criminals operating in Italy. For example, the DIA's most recent bi-annual reports all contain a chapter devoted to 'criminalità organizzate straniere' (foreign organised criminalities) (see Ministero dell'Interno 2000; 2001a; 2005a; 2006a).

Since the early 1980s, Italy has undergone a process of internationalisation and ethnicisation of its illegal markets. This trend, which started in other western European countries in the 1950s, developed rapidly in Italy from the late 1980s on, when the country also became the destination of significant migration flows. All over Europe, the internationalisation of illegal markets was strongly accelerated in the 1990s by the European integration process and the abolition of border controls as well as by the radical transformations that occurred in central and eastern Europe. Paradoxically, in Italy the internationalisation of illegal markets was also favoured by the success of the law enforcement forces in the 1990s in dismantling the strongest branches of the mafia groups in the centre and north of Italy. The empty spaces, once controlled by the powerful clans of the Calabrian 'Ndrangheta and the Sicilian mafia, are today occupied by various groups and gangs of different ethnic origin and composition (Paoli 2000: ch. 4).

As a result, today in Milan as in Rome, Frankfurt, London or Amsterdam, illicit goods and services are offered and exchanged by a variety of multi-ethnic peoples. Next to mafiosi and local criminals, one finds illicit entrepreneurs from all parts of the world. A few of these 'ethnic' criminals - in particular, some of the Chinese - exercise a form of 
political power within their own communities (Suchan 2001), much like the Sicilian and Calabrian mafiosi in their own strongholds. However, most of the foreign criminal groups and actors active in Italy have no claim to political authority. They content themselves merely with making quick money by trading in illicit commodities and/or reinvesting dirty money from their home countries in the European Union and, specifically, in Italy.

Their internal composition is also quite different from that of the southern Italian mafia families. Foreign crime groups and gangs active in Italy have nothing like the longevity and organisational complexity of southern Italian mafia organisations. Some of them are family businesses or organisations cemented together by profit-making or by shared revolutionary or ideological goals; many more are loose gangs, founded on ties of friendship and locality. These are usually small, ephemeral enterprises that can be most correctly described as 'crews': loose associations of people which form, split, and come together again as the opportunity arises. In crews, positions and tasks are usually interchangeable and exclusivity is not required: indeed, many crew members frequently have overlapping roles in other criminal enterprises (e.g., Paoli 2002).

Illegal market groups and crews are by no means composed exclusively of foreigners. Besides the members of mafia and pseudo-mafia groups, at all levels of Italy's illegal markets we also find people belonging to the mainstream population with no previous underworld connections. It is enough to say that two of Milan's largest cocaine importers in the late 1990s were neither mafia members nor foreigners, but Italians who simply belonged to the sphere of white-collar crime. The first was a Milanese, who invested money earned from loan-sharking in the drugs business and was able to import 600-800 kilograms of cocaine directly from Colombia each time. The second was a former bank manager from Naples, who was responsible for several 400-700 kilogram cocaine shipments. Both supplied a plurality of wholesale traffickers, including members of southern Italian mafia groups, in numerous parts of the country (Paoli 2000: 110-15).

As such, the 'new' illegal market players fit better into the 'entrepreneurial' definitions of organised crime that are en vogue in northern and central Europe than into the mafia-centred understanding of organised crime that is widespread in Italy. Despite the lack of empirical proof, however, foreign illicit entrepreneurs are all too frequently labelled as mafia and believed to be organised in the same way as Cosa Nostra and the 'Ndrangheta. Sooner or later - in Italy and elsewhere - we will have to discuss seriously these assumptions and the opportunity of employing the instruments developed in anti-mafia campaigns in the fight against this 'other' form of organised crime. For if we take the Italian understanding of the concept as a parameter, these new forms of crime are not nearly as well organised as is frequently claimed to be the case. 


\section{Policies against the Mafia and Organised Crime}

The substantial law enforcement successes of the past ten years were achieved within a relatively stable legislative and institutional policy framework. In that decade, in fact, direct anti-mafia policies were not subject to any major upheavals. The successes of the last ten years, however, rest upon the legislative and institutional innovations introduced in the early 1990s, both before and immediately after the murders of judges Falcone and Borsellino in May and July 1992.

\section{The Legislative and Institutional Innovations of the Early 1990s}

In 1991 two decree-laws (converted into law with Acts No. 82/1991 and No. 203/1991) set up a formal policy regime for the so-called collaboratori $e$ testimoni di giustizia providing evidence for the fight against mafia crime: the collaboratori are defectors from organised crime groups (improperly called pentiti); testimoni, much more reduced in number, are private witnesses or victims. The new legislation granted mafia defectors special sanctioning and penitentiary benefits and ensured all witnesses state protection, financial assistance and even the possibility of changing residence and identity. The bills also set up the Servizio Centrale di Protezione, which is in charge of ensuring the security and the eventual custody of the witnesses and helping them in all practical respects.

Two major institutional innovations were also introduced before the Capaci and Via D'Amelio attacks, in which Giovanni Falcone and Paolo Borsellino were killed. To overcome the fierce competition among Italy's three major police forces (Polizia di Stato, Arma dei Carabinieri and Guardia di Finanza), the Direzione Investigativa Antimafia was created in late 1991 (by Decree-Law No. 345/1991, converted by Act No. 410/1991). The DIA staff (approximately 1,500 units) comes, in equal proportion, from these three police forces. According to Act No. 410/1991, the DIA's mission is 'to ensure the implementation, in a coordinated manner, of intelligence activities targeting organised crime and to conduct investigations exclusively concerning mafia or mafia-related offences'. Despite its law enforcement successes, the DIA has largely failed in the goal it was originally set up to achieve: namely, to coordinate and eventually integrate all mafia-related investigations. Due to the opposition of the other three police forces, the DIA has de facto become the fourth competitor in Italy's already overcrowded law enforcement arena.

The judicial counterpart of the DIA is the Direzione Nazionale Antimafia (DNA), which coordinates the 26 Direzioni Distrettuali Antimafia (DDAs). Originally opposed by most Italian magistrates, who were fearful of losing their autonomy, Decree-Law No. 367/1991 was finally converted into Act No. 8/1992 thanks only to Giovanni Falcone's tenacious sponsorship of the project. The DNA cannot carry out investigations on its own, but can 
obtain information, including that relating to the existence of an offence, which is frequently derived from collaborators' statements. The DNA also calls frequent meetings with the DDAs in order to harmonise interpretations and procedures. In their turn, the DDAs centralise anti-mafia inquiries within each district. It is fair to say that since the mid-1990s, the coordination activities of the DNAs and (even more so) of the DDAs have become an invaluable instrument in the fight against the mafia.

Next to the witness statute, the second major legislative innovation of the early 1990s was a veritable emergency measure, which was enacted in the form of a decree-law in June and finally converted into law in August 1992 after the Via D'Amelio (Borsellino) killings (Act No. 356/1992). The bill granted additional responsibilities to the DIA and judiciary police for wiretappings, searches and questionings; introduced new offences and different procedures for anti-mafia trials, and recognised as judicial evidence testimonies obtained by the prosecutor's office during the preliminary inquiries, even if they were not confirmed during the public hearings; and allowed for videoconference questioning of mafia witnesses to avoid endangering their security. Its most effective provision, however, was the introduction of a special detention system for the leaders of mafia associations (Art. 41bis of Act No. 354/1975).

The early 1990s also saw the beginning of what we referred to earlier as indirect anti-mafia policies: namely, policies not anchored in criminal or criminal procedural law but having a more administrative and civil law nature. Two exemplary pieces of legislation were passed in 1991. DecreeLaw No. 164/1991 (converted by Act No. 221/1991), for example, allows for the dissolution of municipal and provincial councils and the suspension or dismissal of mayors and presidents of provinces or regions when there is evidence of a connection between local administrators and mafiosi. In same year, the first anti-racket law (Decree-Law No. 419/1991 converted by Act No. 172/1992) was also approved, following the murder of the entrepreneur Libero Grassi, who had publicly announced his decision to refuse to make payments to the racket. The bill aimed at compensating for the various costs experienced to people who resist the racket.

\section{The Last Ten Years: Surprising Continuities in Direct Anti-mafia Policies}

From 1994 onwards, the law enforcement fight against the mafia gradually lost political and public support. Portrayed for a few years as heroes, the public prosecutors of Palermo and other southern Italian cities became the object of ever more virulent criticism over time. They were accused of relying excessively on pentiti's statements and confessions and accusing high-ranking politicians and civil servants of giving support to mafia groups without sufficient evidence.

Prompted by the personal interests of their leader, Silvio Berlusconi, Forza Italia and the centre-right coalition contributed substantially to the 
change in political and public attitudes regarding the prosecutors and their investigative methods. Despite the strong prejudice against all magistrates, however, neither Berlusconi's first government in 1994 nor his second and third during 2001-06 introduced any radical innovations in anti-mafia policies. Only two major reforms of direct anti-mafia policies were adopted in the 12-year period 1994-2006 and they were both adopted by left-wing majorities (albeit, with the support of the right-wing opposition). Act No. $45 / 2001$ revised the legislation on witnesses, with several aims in mind. It promoted the cooperation of witnesses not coming from mafia ranks; it imposed on mafia defectors the obligation to reveal assets earned illicitly and to serve at least part of their sentences; it required a cross-examination of witnesses' declarations during a trial; and it prohibited 'statements by instalments', forcing pentiti to declare all they know within six months.

This piece of legislation, as well as the harsh polemics concerning pentiti that preceded their adoption, caused a reduction in the number of new mafia defections. Even more relevant in that respect were the inefficiencies of the Servizio Centrale di Protezione that, according to some observers, from the late 1990s onwards pursued the clear objective of reducing the number of protected collaboratori di giustizia (Spataro 2000). While their overall number fell only moderately (at the end of 2004, 968 organised crime defectors were under state protection), there was a considerable reduction in the number of new defectors and witnesses admitted to the programme and a parallel growth in the annulment of protection contracts (see Table 3 ).

Act No. 63/2001 (regarding the so-called 'fair trial', which also required a constitutional amendment) introduced some general innovations, some of which are also important for mafia trials. In a nutshell, the act invalidated

TABLE 3

DEFECTORS AND WITNESSES UNDER THE SPECIAL PROTECTION PROGRAMME AND NEW ADMISSIONS TO THE PROGRAMMES, 1992-2005

\begin{tabular}{lccc}
\hline & $\begin{array}{c}\text { Defectors under } \\
\text { protection }\end{array}$ & $\begin{array}{c}\text { Witnesses under } \\
\text { protection }\end{array}$ & $\begin{array}{c}\text { New admissions to the } \\
\text { programme }\end{array}$ \\
\hline 1992 & - & - & 17 \\
1993 & - & - & 98 \\
1994 & - & - & 282 \\
1995 & 1,052 & 67 & 397 \\
1996 & 1,214 & 59 & 338 \\
1997 & 1,028 & 56 & 131 \\
1998 & 1,041 & 55 & 199 \\
1999 & 1,100 & 56 & 151 \\
2000 & 1,100 & 61 & 91 \\
2001 & 1,104 & 74 & 59 \\
2002 & 1,098 & 64 & 84 \\
2003 & 1,119 & 65 & 117 \\
2004 & 968 & 71 & 65 \\
2005 first six months & 927 & 73 & 36 \\
\hline
\end{tabular}

Source: Ministero dell'Interno, 2005c: 8, 12. 
all statements by witnesses that could not be confirmed at the trial stage, and restricted the possibility of making connections between trials, favouring distinct, less complex and hopefully quicker lawsuits. Most prosecutors and judges sharply criticised these new provisions for not taking into account the peculiarities of mafia organised crime and for making witnesses, particularly mafia defectors, vulnerable to mafia intimidation and threats (e.g. Di Matteo et al. 2001).

Almost paradoxically, the only direct anti-mafia policy provision passed by the Berlusconi government was Act No. 279/2002 which confirmed, made permanent and extended the special incarceration regime for persons convicted of mafia-related crimes. The abolition of this special incarceration regime had been the most pressing request of imprisoned mafia bosses. Except for this provision, however, the general judicial legislation of Berlusconi's government was far from being supportive of prosecutors and judges' work. Besides a series of ad personam bills to solve the judicial problems of the Prime Minister and his closest associates (see Hibberd 2007; Della Porta and Vannucci 2007), the reform of the judicial order proposed by the Justice Minister Roberto Castelli provoked the uproar of the entire Italian magistracy, which went on strike, en masse, four times.

Castelli's proposed reform, moreover, did not address the dramatic slowness and inefficiency of the Italian judicial system. While the problem is general and well-known, it is exacerbated in the anti-mafia sector by the current imbalance in personnel and resources between prosecutors' offices (which were strengthened in the early 1990s) and the courts. The lack of staff and judges in courts occasionally threatened to annul even large-scale antimafia investigations. In April 1998, for example, the Reggio Calabria court was obliged to free 62 of the 280 defendants in the penal proceeding known as Olimpia, as the period for preventive detention had elapsed (CPM 2000: 47-51). To prevent further releases, the D'Alema government had to adopt an emergency measure (Act No. 4/2001), which made no attempt, however, to get to the root of the problem.

\section{Innovations in Indirect Anti-mafia Policies}

While direct anti-mafia policies have remained surprisingly stable during the past ten years, numerous changes have affected indirect anti-mafia policies, which were either reformed or adopted for the first time. In 1996, Act No. 162 allowed the utilisation of assets confiscated from mafiosi for social purposes and set up a commissioner for the management of confiscated goods, which was then substituted in 2003 by the Agenzia del Demanio (State Property Agency). This agency is finally trying to make a survey of the confiscated assets and estimate their value correctly, and to speed up the procedures concerning the concrete utilisation of confiscated assets. However, out of 6,866 immovable properties confiscated since 1985, only 
3,147 had been transferred to their final destination by the end of 2005 (Corte dei Conti 2006: 20).

After many stops and starts, in 1999 the Autorità per la Vigilanza sui Lavori Pubblici (Authority for the Surveillance of Public Works) began its work to guarantee legality, efficiency and accountability in the public works sector. This independent commission can inspect and sanction firms, as well as require documents and information from any public body concerned. It must then inform the judiciary of any irregularity detected (La Spina 2004: 649).

Act No. 44/1999 reformed the anti-racket law passed in 1991, which had proved to be too bureaucratic and ineffective. The new bill increased the benefits granted to racket victims and extended the types of reimbursable damages, speeded up the money transfers, involved NGOs in the selection processes of grantees, eased the victims' obligations of cooperation with investigators, and created an ad hoc commissioner, who is also responsible for coordinating actions against usury. Between 1999 and 2005, the committee headed by this commissioner provided financial support in 1,092 cases (627 extortions cases and 465 for usury), distributing over $€ 91$ million (Ministero dell'Interno 2006b).

Many regional and local public institutions work to support the spread of collective movements against the mafias as well as to sensitise younger generations to the problem, especially in schools. Another instrument used at the local level to reduce mafia influence in the legal economy are the so-called patti territoriali and contratti d'area. These contracts, usually signed by municipalities, other public administrations, entrepreneurs and their organisations as well as social partners, aim at promoting the socioeconomic development of a specific area. Most of these include "legality protocols', through which the parties assume reciprocal obligations to prevent organised crime infiltration in both the economic and social life of the area (La Spina 2004: 649).

The security and development of the Mezzogiorno is also fostered by the Programma Operativo Nazionale (PON), which is largely funded by the European Fund for Regional Development and the European Social Fund. The current PON is called 'Sicurezza per lo Sviluppo del Mezzogiorno d'Italia 2000-06' (hence PON SDN) and has an endowment of $€ 1,120$ million. Its overall objective is to create security conditions in southern Italy comparable to those existing in the centre-north and capable of stimulating the economic and social development of southern regions. More specific objectives include a further spread of new technologies to provide security, effectively control the territory and protect cultural and environmental resources (which was the primary objective of the first PON SDN 1994-99); quicker responses and decisions by police forces and courts; and the spread of a culture of legality with a series of initiatives targeting young people (Ministero dell'Interno 2005b: 206-8). 


\section{Concluding Remarks: The Beginning of an Evaluation}

The radical and painful changes undergone by the four principal sets of organised crime and mafia groups in southern Italy are the best proof of the effectiveness of anti-mafia law enforcement action. As shown in this article, the Sacra Corona Unita, which used to be the most powerful Apulian criminal organisation, has been disbanded; many of the most structured Campanian criminal groups have been critically weakened and their leaders arrested; Cosa Nostra itself has seen all of its high-ranking members of the 1980s and 1990s arrested, has been excluded from most international trafficking and has lost political power. Out of the four major southern Italian organised crime types, the 'Ndrangheta is currently in the best condition but many of its families, too, have been decimated by arrests, convictions and asset confiscations. However, the capacity of mafia groups to survive and regenerate should not be underestimated: Cosa Nostra, in particular, re-emerged strengthened from the two previous waves of sharp repression in the 1920s-early 1930s and during the 1960s. Recognising mafia groups' current crisis does not mean that they are defeated or that the law enforcement campaign against the mafia should be relaxed.

True, some of the recent legislative innovations concerning trial rules and mafia witnesses' treatment have probably diminished the capacity of the police and public prosecutors to produce new information as well as new convictions of suspected mafiosi. However, as some representatives of the judiciary are well aware, the 'loss' in effectiveness can be counterbalanced by a crucial gain in legitimacy. The more legitimate anti-mafia policies are perceived to be, the more effective they are likely to become in the future.

This judgement is more nuanced in the case of indirect anti-mafia policies. The first version of the anti-racket legislation was totally unsuccessful: financial resources devoted to it remained largely unspent. The sums distributed by the new commissioner since 1999 have been more consistent. However, mafia racketeering remains very widespread. According to estimates produced by entrepreneurial associations, 50 to 80 per cent of shopkeepers in most southern towns still pay the pizzo for 'protection' (Svimez 2001: 909). A further unmistakable indicator of ineffectiveness is the fact that from 1996 onwards the number of extortion reports did not grow, but rather decreased. There are other signs of deterioration. In the first three years of the application of Act No. 221/91, 76 city councils were dismissed because they had been 'polluted' or influenced by the mafia. Since then, the number of dismissed city councils has steadily decreased, even though there are no signs that mafia attempts to influence and control public life at the local level have diminished (Paoli 2003: 206; Ministero dell'Interno 2005b: 25-6).

Nor do 'top-down' initiatives aimed at spreading a culture of legality look particularly effective at first glance, despite the lack of any feedback on their impact. According to La Spina (2004: 671), Sicilian experiences are 
discouraging, as they seem to have become, for many schools, simply one of many routine paperwork activities. A similar judgement can probably be extended to the legality protocols, whose impact in terms of an increase in security standards is also impossible to assess. In many cases, the main goal of such protocols seems to be that of enabling the subscribers to participate in the distribution of the funds to enhance security (Svimez 2001: 921). A very different assessment should be made of the 'grassroots' initiatives of a more spontaneous kind, which in important cases have contributed to a genuine anti-mafia social mobilisation (Ramella and Trigilia 1997).

It is still too early and in any case difficult to evaluate the effectiveness of the legislation on public works and procurements that aims to prevent mafia infiltration. The newly commenced cooperation between the Authority for the Supervision of Public Works, the DNA, the DIA, and the relevant ministries looks very promising, while ad hoc solutions experimented with in Sicily have been disastrous (La Spina 2004: 671).

Finally, as La Spina (2004: 671-2) points out, the PON SDN can be regarded as a success story. The PON SDN is not only much better managed than most other EU-funded projects in Italy, but also reveals a high level of performance in terms of policy implementation. In fact, in 2004, the PON SDM was the only programme in Europe that coupled the goal of socio-economic development with that of providing security, and is considered a 'best practice' in the European Union.

Despite the PON SDN's success, however, there is still a long way to go in reducing the chronic underdevelopment of some parts of southern Italy, which is usually worse where mafia and organised crime are the strongest. Suffice to say that for much of the past decade the unemployment rate in Calabria and some Sicilian provinces, such as Catania, Palermo and Enna, has oscillated between 28 and 35 per cent and in 2005 was still as high as 18.6 per cent for the whole Mezzogiorno (Svimez 2006). Youth unemployment is even more dramatic. In Calabria, for example, youth unemployment (i.e., among 15 to 25 year olds) was as high as 66 per cent in 1999, with a peak of 71 per cent in the province of Reggio Calabria (CPM 2000). Given these conditions, a career in the mafia or crime still looks attractive to many youngsters with poor education and few hopes of finding a job in the legal economy, and who thus provide an inexhaustible reserve army of criminal manpower. Despite the recent law enforcement successes in the fight against the mafia, therefore, the road ahead is still a long one and it would be a terrible mistake to claim premature victory.

\section{Notes}

1. A veritable uproar was caused by Pino Arlacchi's prognosis, stated at the opening for signature of the UN Convention against Transnational Organized Crime in Palermo in December 2000, that Cosa Nostra was on the verge of defeat. Giovanni Falcone's sisters even wrote an open letter to the President of the Republic, Carlo Azeglio Ciampi, to 
stigmatise such a dangerous underestimation of the mafia phenomenon. An article of mine discussing the reasons of Cosa Nostra's decline (Paoli 2001) also drew a prompt and harsh critique in a reply from a Sicilian sociologist and anti-mafia activist (Dino 2001). Likewise, when Giovanni Fiandaca (2002), a professor of criminal law and member of the Consiglio Superiore della Magistratura, published an article in La Repubblica suggesting a crisis of Cosa Nostra, several public prosecutors, judges, and academics immediately felt the need to respond that his position was wrong.

2. I use the distinction between direct and indirect policies advanced by La Spina (2004) to structure my analysis. As La Spina himself points out, it is a crude distinction. On the one hand, the implementation of criminal law provisions may also have 'social' effects, such as the spreading of a culture of legality. On the other, indirect anti-mafia policies, such as antiracket and public works provisions, also have implications for criminal law.

3. Cosa Nostra and the 'Ndrangheta do not exhaust the panorama of organised crime even in their home regions. In Sicily several other mafia and pseudo-mafia groups are active and the largest ones, such as the Stidda in the Agrigento and Caltanissetta provinces and the Laudani, Cursoti and Pillera-Cappello in Catania, have at some point even successfully challenged the local Cosa Nostra groups. The northern provinces of Calabria also host a plurality of crime groups and gangs, of which only the most structured and powerful have close relationships with the 'Ndrangheta families of the southern provinces. The supremacy of the latter, however, has never been openly challenged.

4. The value of seized assets is roughly estimated by the local police sections at the moment of seizure. A careful evaluation of the asset value is carried out only when the confiscation decision is final and the assets have to be incorporated into the state property or sold by auction.

5. Giulio Andreotti is one of the most important politicians in the post-war period: he has been a member of parliament since 1948, prime minister seven times, and a government minister countless times.

\section{References}

Becchi, Ada, and Margherita Turvani (1993). Proibito? Il mercato mondiale della droga. Rome: Donzelli.

Cordella, Silvia (2006). 'Matteo Messina Denaro: il re di Trapani', Antimafia Duemila, 3, $7-10$.

Corte dei Conti (2006). Relazione sul risultato del controllo eseguito sulla gestione dell'Agenzia del Demanio per gli esercizi 2004 e 2005. Rome: Corte dei Conti.

CPM (Commissione Parlamentare d'inchiesta sul fenomeno della mafia e sulle altre associazioni similari) (2000). Relazione sullo stato della lotta alla criminalità organizzata in Calabria, doc. XXIII, no. 42, XIII Legislature. Rome: Camera dei Deputati.

Cressey, Donald (1969). Theft of the Nation. New York: Harper and Row.

Della Porta, D. and A. Vannucci (2007). 'Corruption and Anti-Corruption: The Political Defeat of "Clean Hands" in Italy', West European Politics, 30:4, 830-53.

DIA (Direzione Investigativa Antimafia) (2007). Rilevazioni statistiche. Available at http:// www.interno.it/dip_ps/dia/pagine/rilevazioni_stat.htm (accessed January 2007).

Di Matteo, Antonino, Franca Imbergamo and Luca Tescaroli (2001). 'Perché mai un mafioso dovrebbe pentirsi?', Micromega, 2, 203-15.

Dino, Alessandra (2001). 'La mafia del Gattopardo', Micromega, 4, 206-20.

Fiandaca, Giovanni (2002). 'Cosa Nostra: una mafia sulla via del declino?', La Repubblica Palermo, 23 July.

Franchetti, Leopoldo (1993 [1876]). Condizioni politiche ed amministrative della Sicilia. Reprint. Rome: Donzelli.

Hibberd, M. (2007). 'Conflicts of Interest and Media Pluralism in Italian Broadcasting', West European Politics, 30:4, 881-902. 
La Spina, Antonio (2004). 'The Paradox of Effectiveness: Growth, Institutionalisation and Evaluation of Anti-Mafia Policies in Italy', in Cyrille Fijnaut and Letizia Paoli (eds.), Organised Crime in Europe: Concepts, Patterns and Policies in the European Union and Beyond. Dordrecht: Springer, 641-76.

Lestingi, F. (1884). 'L'associazione della Fratellanza nella provincia di Girgenti', Archivio di psichiatria, antropologia criminale e scienze penali, 5, 452-63.

Lodato, Saverio (1999). Ho ucciso Giovanni Falcone. La confessione di Giovanni Brusca. Milan: Mondadori.

Loi, Maria (2006). 'In carcere il Gotha di Cosa Nostra: I pizzini di Provenzano svelano i nuovi capi', Antimafia Duemila, 3, 2-6.

Massari, Monica (1998). La Sacra corona unita. Potere e segreto. Rome-Bari: Laterza.

Ministero dell'Interno (1997). Relazione sui programmi di protezione, sulla loro efficacia e sulle modalità generali di applicazione per coloro che collaborano alla giustizia - II semestre 1996. Rome: Ministero dell'Interno.

Ministero dell'Interno (2000). Relazione semestrale sull'attività svolta e $i$ risultati conseguiti dalla Direzione Investigativa Antimafia nel secondo semestre del 1999. Rome: Ministero dell'Interno.

Ministero dell'Interno (2001a). Relazione semestrale sull'attività svolta e $i$ risultati conseguiti dalla Direzione Investigativa Antimafia nel secondo semestre del 2000. Rome: Ministero dell'Interno.

Ministero dell'Interno (2001b). Rapporto sullo stato della sicurezza in Italia 2001. Rome: Ministero dell'Interno.

Ministero dell'Interno (2001c). Rapporto sul fenomeno della criminalità organizzata (anno 2000). Rome: Ministero dell'Interno.

Ministero dell'Interno (2002). Relazione semestrale sull'attività svolta e $i$ risultati conseguiti dalla Direzione Investigativa Antimafia nel primo semestre del 2002. Rome: Ministero dell'Interno.

Ministero dell'Interno (2005a). Relazione semestrale sull'attività svolta e $i$ risultati conseguiti dalla Direzione Investigativa Antimafia nel secondo semestre del 2004. Rome: Ministero dell'Interno.

Ministero dell'Interno (2005b). Rapporto sullo stato della sicurezza in Italia 2005. Rome: Ministero dell'Interno.

Ministero dell'Interno (2005c). Relazione al Parlamento sulle speciali misure di protezione, sulla loro efficacia e sulle modalità generali di applicazione - 1 gennaio-30 giugno 2005. Rome: Ministero dell'Interno.

Ministero dell'Interno (2006a). Relazione semestrale sull'attività svolta e $i$ risultati conseguiti dalla Direzione Investigativa Antimafia nel secondo semestre del 2005. Rome: Ministero dell'Interno.

Ministero dell'Interno (2006b). Dati relativi all'attività svolta dal Comitato di solidarietà per le vittime dell'estorsione e dell'usura nel periodo che va dal 1999 al 2004. Available at http:// www.interno.it/news/articolo.php?idarticolo=21482. Rome: Ministero dell'Interno.

Ministero della Giustizia, Dipartimento dell'Amministrazione Penitenziaria (2006). Rapporto sulla situazione degli istituti penitenziari per l'anno 2005. Rome: Ministero della Giustizia.

Monzini, Paola (1999). Gruppi criminali a Napoli e a Marsiglia. La delinquenza organizzata nella storia delle due città (1820-1990). Rome: Meridiana.

Paoli, Letizia (2000). Pilot Project to Describe and Analyse Local Drug Markets - First Phase Final Report: Illegal Drug Markets in Frankfurt and Milan. Lisbon: EMCDDA.

Paoli, Letizia (2001). 'La mafia è sconfitta?', Il Mulino, L (May-June): 477-85.

Paoli, Letizia (2002). 'The Paradoxes of Organised Crime', Crime, Law and Social Change, 37:1, 51-97.

Paoli, Letizia (2003). Mafia Brotherhoods: Organized Crime, Italian Style. New York: Oxford University Press.

Pezzino, Paolo (1987). 'Stato violenza società. Nascita e sviluppo del paradigma mafioso', in M. Aymard and G. Giarrizzo (eds.), La Sicilia. Turin: Einaudi, 905-84. 


\section{L. Paoli}

Ramella, Francesco, and Carlo Trigilia (1997). 'Associazionismo e mobilitazione contro la criminalità organizzata nel Mezzogiorno', in L. Violante (ed.), Mafia e società italiana. Rapporto '97. Bari-Rome: Laterza, 24-46.

Sales, Isaia (2001). 'Camorra', in Enciclopedia Treccani (ed.), Appendice 2000. Rome: Treccani, 468-9.

Scarpinato, Roberto (1992). 'Mafia e politica', in Mafia. Anatomia di un regime. Rome, Librerie Associate.

Spataro, Armando (2000). 'Ragione e pentimento', Micromega, 1, 57-67.

Suchan, Pietro (2001). 'La criminalità organizzata cinese in Toscana', in Monica Massari and Stefano Becucci (eds.), Mafie nostre, mafie loro. Criminalità organizzata italiana e straniera al Centro Nord. Milan: Comunità.

Svimez (2001). Rapporto 2001 sull'economia del Mezzogiorno. Bologna: Mulino.

Svimez (2006). Rapporto 2006 sull'economia del Mezzogiorno - Sintesi. 11 July.

Weber, Max (1978 [1922]). Economy and Society. ed. G. Roth and C. Wittich. Berkeley: University of California Press. 
Copyright of West European Politics is the property of Routledge and its content may not be copied or emailed to multiple sites or posted to a listserv without the copyright holder's express written permission. However, users may print, download, or email articles for individual use. 